American Journal of Pharmacology and Toxicology 4 (2): 29-37, 2009

ISSN 1557-4962

(C) 2008 Science Publications

\title{
Cardioprotective Effect of Cucumis trigonus Roxb on Isoproterenol-Induced Myocardial Infarction in Rat
}

\author{
${ }^{1}$ B.S. Thippeswamy, ${ }^{2}$ S.P. Thakker, ${ }^{3}$ S. Tubachi, ${ }^{4}$ G.A. Kalyani, ${ }^{5}$ M.K. Netra, \\ ${ }^{5}$ U. Patil, ${ }^{5}$ S. Desai, ${ }^{5}$ C.C. Gavimath and ${ }^{6}$ V.P. Veerapur \\ ${ }^{1}$ Department of Pharmacology, Soniya Education Trust's College of Pharmacy, \\ SR Nagar, Dharwad-580 002, Karnataka, India \\ ${ }^{2}$ Department of Pharmaceutics, Soniya Education Trust's College of Pharmacy, \\ SR Nagar, Dharwad-580 002, Karnataka, India \\ ${ }^{3}$ Department of Pharmacology and Pharmacotherapeutics, \\ Karnataka Lingayat Education University, Belgaum-590 010, Karnataka, India \\ ${ }^{4}$ Karnataka Lingayat Education Society's College of Pharmacy, \\ JNMC Campus, Belgaum-590 010, Karnataka, India \\ ${ }^{5}$ Karnataka Lingayat Education Society's College of Engineering and Technology, \\ Udayam Bagh, Belgaum-590010, Karnataka, India \\ ${ }^{6}$ Department of Pharmaceutical Chemistry, Soniya Education Trust's College of Pharmacy, \\ SR Nagar, Dharwad-580 002, Karnataka, India
}

\begin{abstract}
Problem statement: Cиситis trigonus Roxb fruit is used for various ailments in Indian traditional system of medicine such as anthelmintic, liver tonic, cardio tonic, appetizer, expectorant and intellect promoting. However, there is lack of information regarding the effect of Cucumis trigonus on the cardiac changes associated with ISO induced myocardial infarction. Approach: The present study was designed to evaluate the cardioprotective potential of ethanol extract of Cucumis Trigonus Roxb fruit (CTE) on the basis of electrocardiographic, biochemical and histopathological parameters in isoproterenol induced myocardial infarction in rats. Male albino sprague dawely rats were pretreated with CTE (75 and $150 \mathrm{mg} \mathrm{kg}{ }^{-1}$ ) daily for a period of 14 days. After the treatment period, ISO $\left(200 \mathrm{mg} \mathrm{kg}{ }^{-1}\right.$ ) was subcutaneously injected to rats at an interval of $24 \mathrm{~h}$ for two days to induce myocardial injury. After $48 \mathrm{~h}$, rats were anaesthetized with anesthetic ether, electrocardiographic and the levels of biochemical and histological observations of the heart tissues were performed. Results: The activities of serum marker enzymes (ALT, AST, LDH and CPK) were increased significantly $(p<0.05)$ in ISO-induced rats. In addition, it also exhibited Electrocardiographic (ECG) changes such as increase heart rate, reduced R-wave amplitude and ST-segment elevation. CTE at concentration of $150 \mathrm{mg} \mathrm{kg}^{-1}$, when administered orally showed a decrease in serum enzyme levels and the ECG changes brought to the near normal values. The observed results were further confirmed by histopathological findings. The histological sections obtained from ISO alone showed various degrees of focal lesions in many sections, consisting molted staining and fragmentation of muscle fibers with confluent retrogressive lesions were observed. Animals treated with CTE demonstrated marked improvement in ISO-induced alterations such as vacuolar changes, edema, capillary dilatation and leukocyte infiltration compared to ISO administered group. Conclusion: Our data showed that CTE $\left(150 \mathrm{mg} \mathrm{kg}^{-1}\right.$, p.o.) significantly restores most of the electrocardiographic, biochemical and histopathological parameters. The present study concluded that CTE may be therapeutic and prophylactic value in the treatment of myocardial infarction.
\end{abstract}

Key words: Cucumis trigonus roxb, isoproterenol, myocardial infarction, cardioprotective

\section{INTRODUCTION}

Ischemic Heart Disease (IHD) is the leading cause of morbidity and mortality in world wide and according to the world health organization it will be the major cause of death in the world by the year $2020^{[1]}$. Myocardial Infarction (MI) results from the prolonged myocardial ischemia with necrosis of

Correspondence Author: B.S. Thippeswamy, Department of Pharmacology, Soniya Education Trust's College of Pharmacy, SR Nagar, Dharwad-580 002, Karnataka, India Tel: +91-836-2448540 Fax: +91-836-2467190 
myocytes due to interruption of blood supply to an area of heart ${ }^{[2]}$.

Isoproterenol (ISO) induced myocardial necrosis is a well known standard model to study the beneficial effect of many drugs on cardiac dysfunction ${ }^{[3]}$. ISO is a $\beta$-adrenergic agonist that causes severe stress in myocardium and necrotic lensions in the heart muscles. ISO induced myocardial injury involves membrane permeability alterations, which brings about the loss of functions and integrity of myocardial membranes ${ }^{[4]}$. MI induced by ISO in rats has been shown to be accompanied by hyperglycemia, hyperlipidemia and increase in serum creatine phosphokinase, alanine aminotransferace, aspertate aminotransferase and lactate dehydrogenase activities ${ }^{[5,6]}$. The mechanism proposed to explain isoproterenol induced cardiac damage involves generation of highly cytotoxic free radicals through auto-oxidation of catecholamine and has been implicated as one of the causative factor ${ }^{[7]}$.

Cardiovascular Diseases (CVD) are the secondary cause of deaths in many parts of the world, although modern drugs are effective in preventing the disorders, their use is often limited because of their side effects and adverse reactions. A wide array of plants and its active principles, with minimal side effects, provide an alternate therapy for Ischemic heart disease. Moreover, the plant kingdom represents a largely unexplored reservoir of biologically active compounds. Cucumis trigonus Roxb of family Cucurbitaceae is distributed throughout India and found in areas of Ceylon, Afghanistan, Persia and Northern Australia. It is used for various ailments in Indian Traditional System of Medicine. Fruit and roots have medicinal value. The fruits are used in flatulence, leprosy, fever, jaundice, diabetes, cough, bronchitis, ascites, anaemia, constipation, other abdominal disorders and amentia. In addition, fruit pulp is bitter, acrid, thermogenic, anthelmintic, liver tonic, cardio tonic, appetizer, expectorant and intellect promoting ${ }^{[8]}$. The title plant is reported to possess analgesic, anti-inflammatory and diuretic activity ${ }^{[9,10]}$. Recently it's proteolytic and serine protease activity has been reported ${ }^{[11,12]}$. However, there is lack of information regarding the effect of Cucumis trigonus on the cardiac changes associated with ISO induced myocardial infarction.

The present study was design to investigate the modulation of ethanol extract of Cucumis trigonus fruit in ISO-induced electrocardiographic, biochemical and histopathological changes.

\section{MATERIALS AND METHODS}

Chemicals: Isoproterenol hydrochloride (ISO) purchased from Sigma Chemical Company, St louis
MO USA, ECG Electrodes procured from Biopac Santa Barbara California. Sodium carboxy methyl cellulose (Na-CMC) from Loba Chemie, Mumbai, India, Pentobarbitone, Anaesthetic ether was used. All chemicals were of analytical grade.

Plant material: The fruits of Cucumis trigonus Roxb were purchased from the local market. The plant was authenticated by a botanist in Department of Krishi Vignana Kendra GKVK Campus, Hebbal, Bangalore and voucher specimen of the plant was kept in the college herbarium.

Extraction: The shade dried and coarse powdered material $(1 \mathrm{~kg})$ was extracted exhaustively with ethanol in a soxhlet apparatus. The extract was concentrated to a small volume using flash evaporator and further evaporated to dryness in a vacuum desiccator. The extracts obtained were in the form of thick paste due to the presence of resinous matter. The yield of ethanol extract is $180 \mathrm{~g}$.

Animals: Male sprague dawley rats of 150-200 g were used for the study. The inbred colonies of rats were purchased from Venkateshwara enterprises, Bangalore. They were acclimatized to controlled conditions of temperature $\left(23 \pm 2^{\circ} \mathrm{C}\right)$, humidity $(50 \pm 5 \%)$ and $12 \mathrm{~h}$ light-dark cycles. The animals were randomized into experimental and control groups and housed two each in sanitized polypropylene cages containing sterile paddy husk as bedding. They had free assessed to standard pellets as basal diet and water ad libitum. All the studies conducted were approved by the Institutional Ethical Committee, KLE Society's College of Pharmacy, Jawaharlal Nehru Medical College, Belgaum, according to prescribed guidelines of Committee for the Purpose of Control and Supervision of Experiments on Animals (CPCSEA/5/08), Government of India. We selected male rats for our studies, since females are shown to be protected from cardiovascular complication ${ }^{[13]}$.

Acute toxicity study: Acute toxicity study was carried out using female Albino Rats (150-200 g) by up and down/staircase method as per OECD guidelines. The CTE was orally administered to different groups of rats at the doses of 50, 300, 1000, 2000 and $3000 \mathrm{mg} \mathrm{kg}^{-1}$ body weight respectively. Animals were observed for $48 \mathrm{~h}$ to study the general behavior of animals, sign of discomfort and nervous manifestation. The CTE was found devoid of mortality of animals at the dose of $3000 \mathrm{mg} \mathrm{kg}^{-1}$ body weight. Hence the 1/20th (150 $\mathrm{mg} \mathrm{kg}^{-1}$, p.o.) and $1 / 40$ th $\left(75 \mathrm{mg} \mathrm{kg}^{-1}\right.$, p.o.) of the 
dose selected for the screening of cardio-protective activity.

Induction of myocardial injury: Rats were treated with different doses of ethanol extract of Cucumis Trigonus (CTE) orally using an intra-gastric tube daily for 14 days. On 14th day, myocardial injury was induced in experimental rats by injection of ISO $\left(200 \mathrm{mg} \mathrm{kg}^{-1}\right.$, s.c.) twice at an interval of $24 \mathrm{~h}$ (i.e., on 14th and 15th day of extract treatment) while normal control and ISO treated rats were given an equivalent volume of the vehicle.

Treatment protocol: The experimental rats were divided into six groups of 6 animals each and treated as follows:

Group 1: Normal Control Rats treated with $1 \% \mathrm{Na}$ CMC $\left[\sim 2 \mathrm{~mL} \mathrm{~kg}^{-1}\right.$ day $^{-1}$, p.o. $]$

Group 2: Rats treated with CTE $\left(75 \mathrm{mg} \mathrm{kg}^{-1} \mathrm{day}^{-1}\right.$, p.o.)

Group 3: Rats treated with CTE (150 mg kg-1 day $^{-1}$, p.o.)

Group 4: Rats treated with $1 \% \mathrm{Na}$ CMC [ 2 $\mathrm{mL} \mathrm{kg}^{-1}$ day $^{-1}$, p.o.] and then ISO (200 $\mathrm{mg} \mathrm{kg}^{-1} \mathrm{day}^{-1}$; for 2 days, s.c.)

Group 5: Rats pretreated with CTE $\left(75 \mathrm{mg} \mathrm{kg}^{-1} \mathrm{day}^{-1}\right.$, p.o.) and then ISO (200 $\mathrm{mg} \mathrm{kg}^{-1} \mathrm{day}^{-1}$; for 2 days, s.c.)

Group 6: Rats pretreated with CTE $\left(150 \mathrm{mg} \mathrm{kg}^{-1}\right.$ day $^{-1}$, p.o. $)$ and then ISO $\left(200 \mathrm{mg} \mathrm{kg}^{-1} \mathrm{day}^{-1}\right.$; for 2 days, s.c.)

Measurement of ECG: At the end of experimental period (after 24h of second ISO injection or 16th day of extract/vehicle treatment) the rats were anaesthetized with light anaesthetic ether and ECGs were recorded using computerized data acquisition system (Biopac MP 35, Santa Barbara, California). Recordings were made on the bi-polar standard lead-I, lead-II and leadIII. In all cases of myocardial infarction, Lead II show the clear, distinct individual waves than Lead I and III. Therefore, ECG was monitored on Lead II only.

Biochemical analysis: After recording the ECG, blood was collected from retro-orbital plexus, serum was separated and used for estimation of marker enzymes. The activities of aspertate Aminotransferase (AST) and alanine Aminotransferase (ALT) in serum were determined spectrophotometrically by the method of Mohur and $\operatorname{Cook}^{[14]}$ and the absorbance was measured at $520 \mathrm{~nm}$ and enzyme activity was expressed as $\mathrm{U} \mathrm{L}^{-1}$.
The Lactate Dehydrogenase (LDH) activity in serum was assayed according to the method of King ${ }^{[15]}$ and the absorbance was measured $520 \mathrm{~nm}$ and the enzyme activity was expressed as $\mathrm{U} \mathrm{L}^{-1}$. The Creatine Phosphokinase (CPK) activity in serum was determined by the method of Okinaka et al. ${ }^{[16]}$ and the absorbance was measured at $640 \mathrm{~nm}$ and the enzyme activity was expressed as IU $\mathrm{L}^{-1}$.

Histopathological studies: At the end of the study, all the rats were sacrificed by cervical decapitation and the hearts were dissected out, washed in ice cold saline. Then myocardial tissue was immediately fixed in $10 \%$ buffered neutral formalin solution. After fixation, tissues were embedded in paraffin and serial sections were cut and each section was stained with hematoxylin and eosin. The slides were examined under light microscope and photographs were taken.

Statistical analysis: The data were expressed as Mean \pm SEM for six rats in each group. Statistical comparisons were performed by one-way ANOVA followed by Tukey's post-test using GraphPad Prism version 4.0, USA.

\section{RESULTS}

Effect of cucumis trigonus roxb on different ECG parameters: Figure 1 shows the electrocardiographic pattern of control and experimental animals. Normal control and different doses of CTE (75 and $150 \mathrm{mg} \mathrm{kg}^{-1}$ ) alone treated rats showed a normal ECG pattern, where as animals treated with ISO alone showed significant elevation in ST segment, reduction in P wave, QRS complex and R-R interval. In addition there was an increase in heart rate, prolongation of QT interval and cardiac cycles compared to normal control animals. Pretreatment of CTE (75 and $150 \mathrm{mg} \mathrm{kg}^{-1}$ ) for 14 days and two doses of ISO (200 mg kg-1) administered rats exhibited normal ECG pattern with a slight elevation in ST segment. Furthermore, treatment also resulted in significant $(\mathrm{p}<0.001)$ increase in $\mathrm{P}$ wave, $\mathrm{QRS}$ complex and R-R interval, whereas heart rate, QT interval and cardiac cycle were maintained near to normal values. The data of the experimental animals such as $\mathrm{P}$ wave, QRS complex, QT interval, R-R interval, heart rate and cardiac cycle are shown in Table 1.

Effect of cucumis trigonus roxb on serum marker enzymes: ISO treated rats exhibited significantly $(\mathrm{p}<0.001)$ higher levels of serum myocardial injury marker enzymes such as AST $\left(405 \pm 14.2 \mathrm{U} \mathrm{L} \mathrm{L}^{-1}\right)$, 
Am. J. Pharm. \& Toxicol., 4 (2): 29-37, 2009

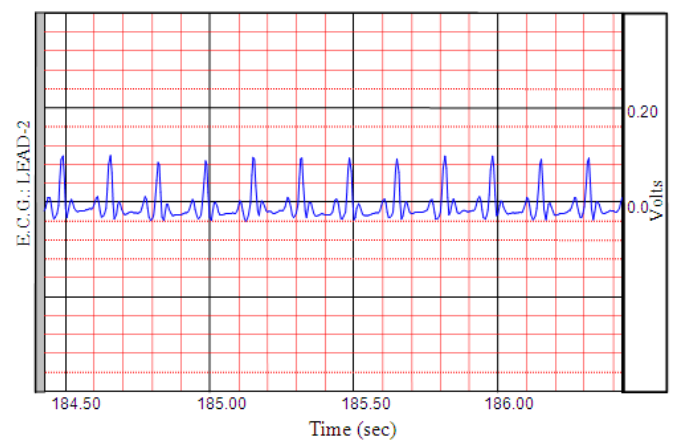

(a)

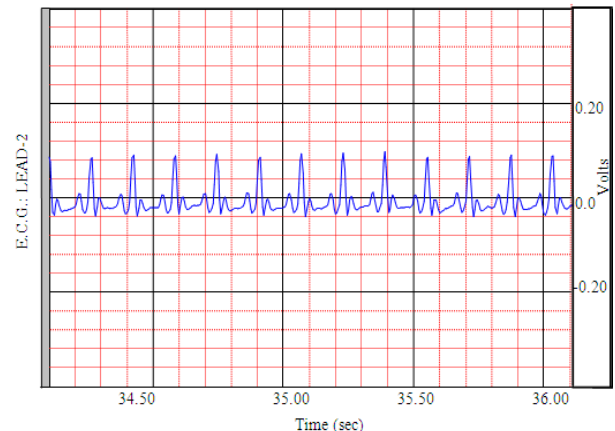

(c)

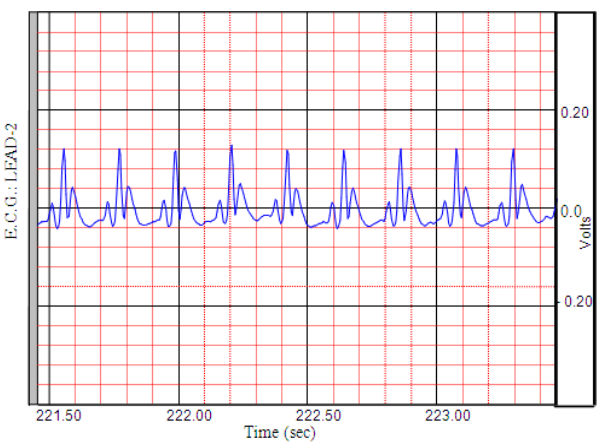

(e)

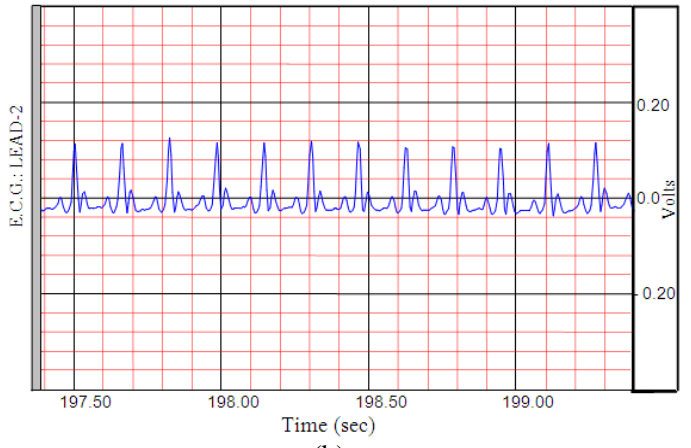

(b)

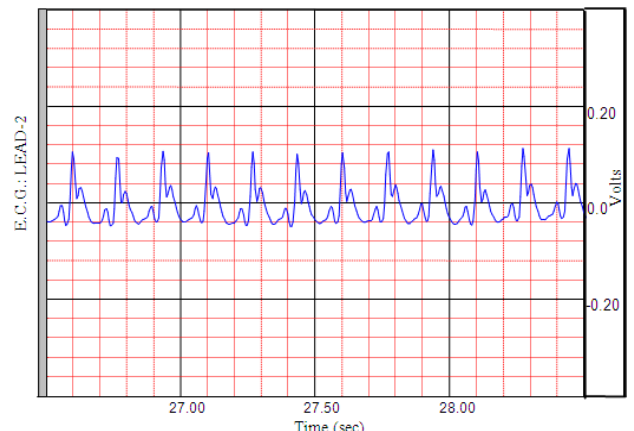

(d)

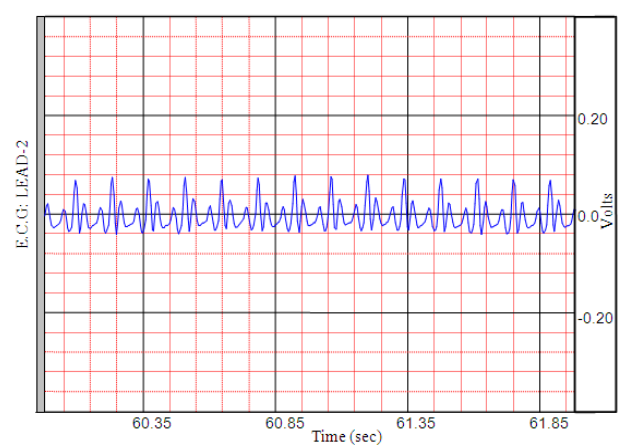

(f)

Fig. 1: Effect of ethanol extract of Cucumis trigonus (CTE) on electrocardiographic pattern of (a): Normal control; (b): CTE (75 mg kg${ }^{-1}$ ); (c): CTE (150 $\left.\mathrm{m} \mathrm{kg}^{-1}\right)$; (d): Isoproterenol (ISO: $200 \mathrm{mg} \mathrm{kg}^{-1}$ ) alone; (e): ISO+CTE $\left(75 \mathrm{mg} \mathrm{kg}^{-1}\right)$ and (f): ISO+CTE $\left(150 \mathrm{mg} \mathrm{kg}^{-1}\right)$ in rats

Table 1: Effect of ethanol extract of Cucumis trigonus (CTE) on different ECG parameters in ISO-induced myocardial infarction in rats

\begin{tabular}{|c|c|c|c|c|c|c|}
\hline Treatment & $\mathrm{P}$ wave & QRS complex & QT interval & $\mathrm{R}-\mathrm{R}$ interval & Heart rate & Cardiac cycle \\
\hline Normal control & $0.03750 \pm 0.0014^{\mathrm{a}}$ & $0.04292 \pm 0.0009^{\mathrm{a}}$ & $0.08500 \pm 0.0033^{\mathrm{b}}$ & $0.1879 \pm 0.0033^{\mathrm{b}}$ & $321.2 \pm 5.87^{\mathrm{b}}$ & $0.1213 \pm 0.0037^{\mathrm{b}}$ \\
\hline CTE $\left(75 \mathrm{mg} \mathrm{kg}^{-1}\right.$, p.o $)$ & $0.03756 \pm 0.0012$ & $0.04132 \pm 0.0007$ & $0.08340 \pm 0.0032$ & $0.1800 \pm 0.0079$ & $325.3 \pm 19.25$ & $0.1203 \pm 0.0019$ \\
\hline CTE (150 mg kg-1, p.o) & $0.03889 \pm 0.0011$ & $0.04278 \pm 0.0008$ & $0.08278 \pm 0.0031$ & $0.1837 \pm 0.0086$ & $328.0 \pm 17.61$ & $0.1200 \pm 0.0029$ \\
\hline ISO (200 mg kg-1, s.c) & $0.03278 \pm 0.0009$ & $0.03833 \pm 0.0014$ & $0.09944 \pm 0.0019$ & $0.1367 \pm 0.0030$ & $417.9 \pm 6.90$ & $0.1361 \pm 0.0033$ \\
\hline $\begin{array}{l}\text { ISO + CTE } \\
\left(75 \mathrm{mg} \mathrm{kg}^{-1}, \text { p.o }\right) \\
\text { ISO + CTE }\end{array}$ & $0.03467 \pm 0.0089$ & $0.03963 \pm 0.0011$ & $0.08713 \pm 0.0012^{\mathrm{a}}$ & $0.1215 \pm 0.0021$ & $378.0 \pm 8.41$ & $0.1284 \pm 0.0038$ \\
\hline$\left(150 \mathrm{mg} \mathrm{kg}^{-1}\right.$, p.o $)$ & $0.03833 \pm 0.0014^{\mathrm{a}}$ & $0.04250 \pm 0.0012^{\mathrm{a}}$ & $0.08233 \pm 0.0016^{\mathrm{a}}$ & $0.1551 \pm 0.0052^{\mathrm{a}}$ & $365.0 \pm 9.35^{\mathrm{b}}$ & $0.1221 \pm 0.0040^{\mathrm{a}}$ \\
\hline
\end{tabular}

Values are expressed as mean \pm SEM for 6 animals in each group. The ECG parameters are expressed in seconds (sec) and the heart rate as Beats Per Minute (BPM). ${ }^{\mathrm{a}}: \mathrm{p}<0.05,{ }^{\mathrm{b}}: \mathrm{p}<0.01$ when compared with ISO group 


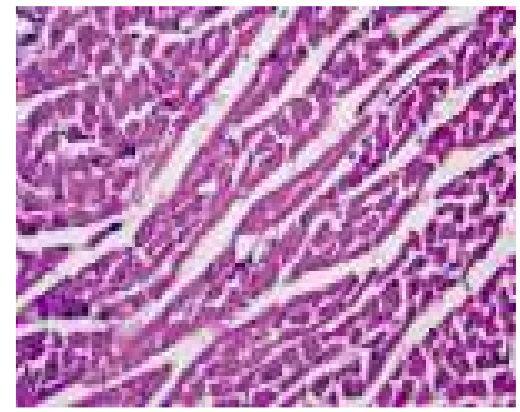

(a)

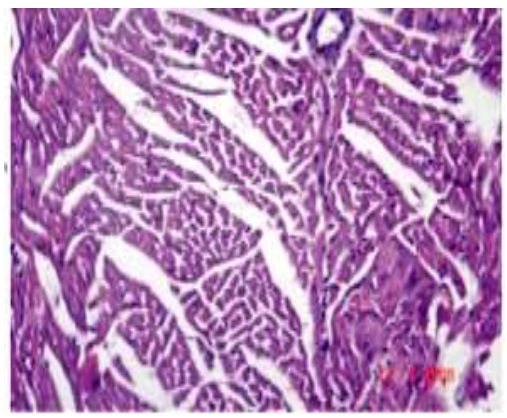

(c)

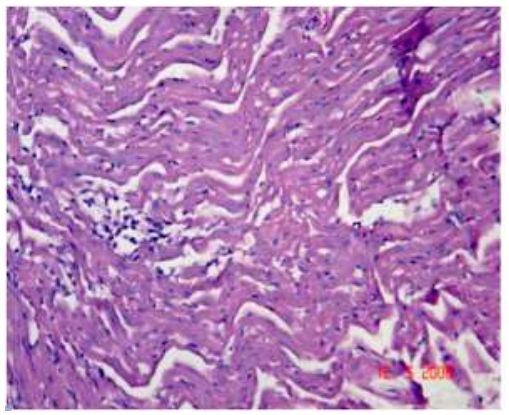

(e)

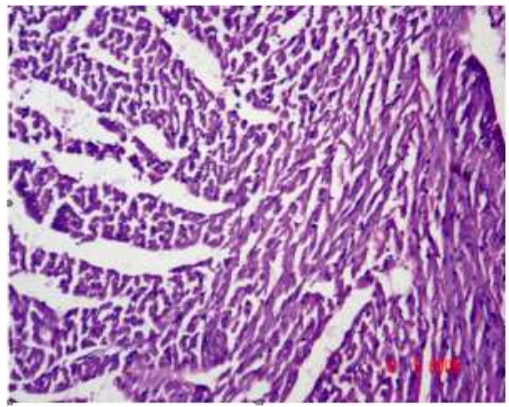

(b)

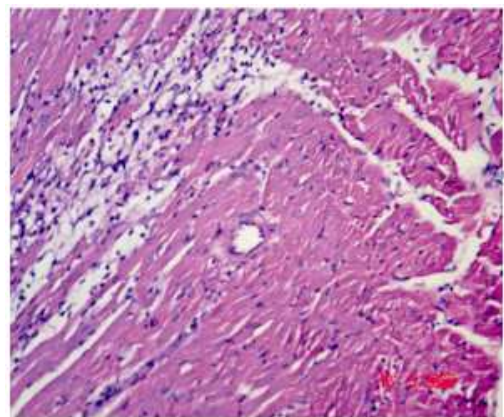

(d)

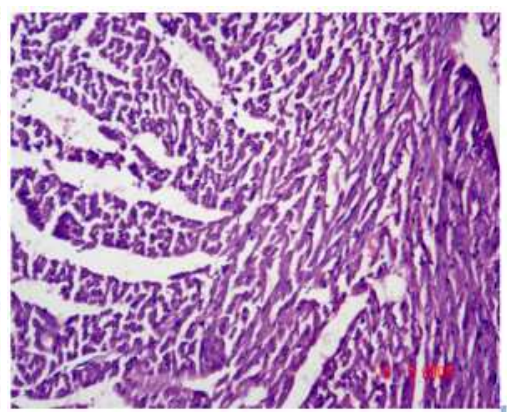

(f)

Fig. 2: Effect of ethanol extract of Cucumis trigonus (CTE) on histopathological changes in rat myocardial tissue [H and E stain, X100]. (a): Normal control showing normal myocardium (b): CTE (75 $\mathrm{mg} \mathrm{kg}^{-1}$ ) showing normal myocardium; (c): CTE (150 mg kg-1) showing normal myocardium (d): Isoproterenol (ISO: $200 \mathrm{mg} \mathrm{kg} \mathrm{g}^{-1}$ ) alone showing fragmentation of myocardial fibers and greater focal interstitial inflammatory response (e): ISO + CTE $\left(75 \mathrm{mg} \mathrm{kg}^{-1}\right)$ showing reduced focal interstitial inflammatory response (f): ISO + CTE $\left(150 \mathrm{mg} \mathrm{kg}^{-1}\right)$ showing reduced fragmentation of myocardial fibers and focal interstitial inflammatory response

$\operatorname{ALT}\left(131.6 \pm 9.78 \mathrm{U} \mathrm{L}^{-1}\right), \mathrm{LDH}\left(3310 \pm 160.7 \mathrm{U} \mathrm{L}^{-1}\right)$ and CPK $\left(1173 \pm 18.5 \mathrm{IU} \mathrm{L}^{-1}\right)$ compared to normal control rats (Table 2). The pretreatment of CTE $\left(150 \mathrm{mg} \mathrm{kg}^{-1}\right)$ for 14 days and ISO (200 mg kg-1, for 2 days) administration showed significant $(\mathrm{p}<0.05 ; \mathrm{p}<0.001)$ reduction in all the tested diagnostic markers. Whereas, lower dose of CTE $\left(75 \mathrm{mg} \mathrm{kg}^{-1}\right)$ showed significant $(\mathrm{p}<0.05 ; \mathrm{p}<0.01)$ reduction only in $\mathrm{LDH}$ and $\mathrm{CPK}$ levels. However there was no change in any of these marker enzyme levels in CTE (75 and $150 \mathrm{mg} \mathrm{kg}^{-1}$ ) treated alone group as compared to normal control group (Table 2).

Histopathological findings: Histopathological examination of myocardial tissue obtained from normal control animals and animals treated with CTE depicted clear integrity of myocardial membrane and an infiltration of inflammatory cells were not seen in these experimental groups (Fig. 2a-c). The histological sections obtained from the hearts of animals receiving 
Am. J. Pharm. \& Toxicol., 4 (2): 29-37, 2009

Table 2: Effect of ethanol extract of Cucumis trigonus (CTE) on different biochemical parameters in ISO-induced myocardial infarction in rats

\begin{tabular}{lllll}
\hline Treatment & AST $\left(\mathrm{U} \mathrm{L}^{-1}\right)$ & ALT $\left(\mathrm{U} \mathrm{L} \mathrm{L}^{-1}\right)$ & LDH $\left(\mathrm{U} \mathrm{L}^{-1}\right)$ & $\left.\mathrm{CPK}^{(\mathrm{IU} \mathrm{L}} \mathrm{L}^{-1}\right)$ \\
\hline Control & $315 \pm 18.0^{\mathrm{c}}$ & $97.00 \pm 4.97^{\mathrm{b}}$ & $2347 \pm 48.3^{\mathrm{c}}$ & $1026 \pm 21.86^{\mathrm{b}}$ \\
CTE $\left(75 \mathrm{mg} \mathrm{kg}^{-1}\right.$, p.o $)$ & $302 \pm 9.6$ & $99.20 \pm 3.72$ & $2363 \pm 22.57$ & $989.4 \pm 23.69$ \\
CTE $\left(150 \mathrm{mg} \mathrm{kg}^{-1}\right.$, p.o) & $296 \pm 8.0$ & $100.0 \pm 2.37$ & $2381 \pm 26.81$ & $976.8 \pm 28.04$ \\
ISO $\left(200 \mathrm{mg} \mathrm{kg}^{-1}, \mathrm{s.c}\right)$ & $405 \pm 14.2$ & $131.6 \pm 9.78$ & $3310 \pm 160.7$ & $1173 \pm 18.50$ \\
ISO+CTE $\left(75 \mathrm{mg} \mathrm{kg}^{-1}\right.$, p.o $)$ & $374 \pm 9.4$ & $114.1 \pm 6.42$ & $2831 \pm 127.6^{\mathrm{a}}$ & $1011 \pm 28.56^{\mathrm{b}}$ \\
ISO+CTE $\left(150 \mathrm{mg} \mathrm{kg}^{-1}\right.$, p.o) & $350 \pm 12.6^{\mathrm{a}}$ & $106.2 \pm 4.48^{\mathrm{a}}$ & $2581 \pm 141.8^{\mathrm{c}}$ & $971.2 \pm 32.34^{\mathrm{c}}$ \\
\hline
\end{tabular}

Values are expressed as mean \pm SEM for 6 animals in each group. ${ }^{\mathrm{a}}: \mathrm{p}<0.05 ;{ }^{\mathrm{b}}: \mathrm{p}<0.001 ;^{\mathrm{c}}: \mathrm{p}<0.001$ when compared to ISO alone

ISO alone (Fig. 2d) shows various degrees of focal lesions in many sections consisting of molten staining, fragmentation of muscle fibers with confluent retrogressive lesions were observed. In addition marked sequestering mucoid edema and vacuolar changes along with hyaline necrosis were clearly visible in ISO treated rats. Pretreatment with CTE (75 and $150 \mathrm{mg} \mathrm{kg}^{-1}$, respectively) demonstrated marked improvement in ISO-induced alterations such as vacuolar changes, edema, capillary dilatation and leukocyte infiltration compared to ISO administered group (Fig 2e and f).

\section{DISCUSSION}

Isoproterenol is well known cardiotoxic agent due to its ability it will destruct myocardial cells. As a result of this, cytosolic enzymes such as Lactate Dehydrogenase (LDH), transaminases (ALT, AST) and Creatine Phosphokinase (CPK) were released into blood stream and serve as the diagnostic markers of myocardial tissue damage ${ }^{[17,18]}$. The amount of these cellular enzymes present in blood reflects the alterations in plasma membrane integrity and/or permeability. Drug treatments such as naringin, Silibinin and squalene evidenced by a decline in lactate dehydrogenase, glutamic oxalacetic transaminase and creatine kinase levels indicated their membrane stabilizing action ${ }^{[17,19,20]}$.

In the present study, ISO treated rats showed significant elevation in the levels of these diagnostic marker enzymes (AST, ALT, LDH and CPK). Moreover, elevated levels of these enzymes are an indicator of the severity of ISO-induced myocardial membrane necrosis, which is in line with an earlier report $^{[17,18]}$. The prior administration of CTE (75 and $150 \mathrm{mg} \mathrm{kg}^{-1}$ ) showed significant reduction in ISOinduced elevated serum marker enzymes. This reduction in enzyme levels could be due to its action on maintaining membrane integrity thereby restricting the leakage of these enzymes. It is well known that isoproterenol-induced myocardial injury is mediated primarily via the $\beta_{1}$-adrenergic receptor. Acute $\beta$ adrenergic receptor stimulation not only rapidly generates reactive oxygen species, but also depresses total cellular antioxidant capacity, downregulates copper-zinc superoxide dismutase enzyme activity, protein and mRNA and reduces glutathione level, leading to the loss of membrane integrity and inducing heart contractile dysfunction and myocyte toxicity finally producing myocardial necrosis ${ }^{[21,22]}$. In the present study, we found that CTE protected myocardium from isoproterenol-induced myocardial functional and structural injury via normalization levels of diagnostic marker enzymes.

It is reported that chronic treatment of N-acetylcysteine, S-allylcysteine and $\alpha$-tocopherol ameliorates ISO-induced myocardial toxicity, resulted in stabilization of the cardiac mitochondrial membrane and lysosomal enzymes ${ }^{[23,24]}$. Furthermore, methionine an essential aminoacid is used as a supplement in health food and its deficiency has been associated with a variety of cardiac and vascular changes ${ }^{[25]}$. The similar classes of chemical constituents were reported from the title plant and which is also confirmed by performing preliminary phytochemical analysis of CTE. The observed myocardial protective effect of title plant could be due to the free radical scavenging activity of the extract in the presence of phytochemicals such as sterols and amino acids like arginine, luecine, lysine, cysteine cystine, methionine and phenylalanine ${ }^{[8]}$. These data further confirmed the cardioprotective action of CTE.

Electrocardiograph-abnormalities are the main criteria generally used for the definite diagnosis of myocardial infarction. ST-segment elevation was observed either in patient with acute myocardial ischemia $^{[26]}$ or in isoproterenol-induced myocardial infarction in $\mathrm{rat}^{[27]}$. The study shows significant alterations of ECG patterns were observed in ISO administered rats as compared to normal control rats. The characteristic findings were reductions in the $\mathrm{P}$ wave intensity, QRS complex, R-R intervals, QT interval and prolongation of cardiac cycle. We also observed a significant elevation in the ST segment and increase in heart rate. These alterations could be due to the consecutive loss of cell membrane in injured myocardium $^{[28]}$. In the present study, we observed an elevation of ST-segments in isoproterenol-induced rat 
and pretreatment with CTE markedly inhibited isoproterenol-induced ST-segment elevation suggestive of its cell membrane protecting effects. The appearance of $\mathrm{Q}$ wave and ST segment elevation are some of the indicative signs of ischemia. In the present study we did not observe pathological $Q$ wave due to conditions of ischemia. The prominent $\mathrm{Q}$ wave were seen only on severe ischemia, infarction and in patients with severe heart diseases. The consecutive loss of cellular membrane damage due to oxidative stress might be characterized by ST elevation ${ }^{[28,29]}$. CTE administration showed a protective effect against ISO-induced altered ECG pattern and eliminated the acute fatal complications by protecting the cell membrane damage.

Electrocardiograhic and biochemical findings were further confirmed by histopathological studies. Histopathological examination of myocardial tissue in control depicted clear integrity of the myocardial cell membrane. No inflammatory cells infiltration was seen in the rat heart of normal control. In ISO administered group, focal lesions in many sections consisting of moltled staining and fragmentation of muscle fibres with confluent retrogressive lesions, hyaline necrosis, sequestering mucoid edema were observed. Pretreatment with CTE demonstrated reversal of focal lesions, fragmentation of muscle fibres and retrogressive lesions with hyaline necrosis seen with ISO treated group. Inflammatory cells were seen with reduced density in CTE treated group confirming further the cardioprotective activity exerted by CTE. CTE (150 mg kg-1)-treated normal rats had no toxic effects on cardiac architecture. These data further confirmed the cardioprotective action of oral administration of CTE. Higher dose of isoproterenol induce sub-endocardial ischemia, hypoxia, necrosis and finally fibroblastic hyperplasia with decreased myocardial compliance and inhibition of diastolic and systolic function, which closely resembles local myocardial infarction-like pathological changes seen in human myocardial infarction ${ }^{[30]}$. In the present study, we found that CTE protected myocardium from isoproterenol-induced myocardial functional and structural injury. The data of the present study clearly showed CTE modulated most of the electrophysiological, biochemical and histopathological parameters were maintained to normal status in isoproterenol rats, suggesting the beneficial action of CTE as a cardioprotective agent.

\section{CONCLUSION}

These findings might be rational to understand the beneficial effects of ethanol extract of $C$. trigonus on cardioprotection against myocardial injury. The fruit was found to be most effective in the functional recovery of the heart and restoration of biochemical and histopathological alterations. Further isolation, characterization and purification of the active constituents and further experimentation would be necessary to elucidate the exact mechanism of action of Cucumis trigonus fruits.

\section{ACKNOWLEDGEMENT}

We thank Prof. A.D. Taranalli, Head, Department of Pharmacology, K.L.E.S's College of Pharmacy J.N.M.C; Nehru Nagar; Belgaum; Karnataka for providing necessary facilities and help during the study.

\section{REFERENCES}

1. Lopez, A.D. and C.C. Murrau, 1998. The global burden disease, 1990-2020. Nat. Med., 4: 124-123. http://www.ncbi.nlm.nih.gov/pubmed/9809543

2. Whellan, D.J., 2005. Heart failure disease management: Implementation and outcomes. Cardiol. Rev., 13: 231-239. http://www.ncbi.nlm.nih.gov/pubmed/16106184

3. Wexler, BC., 1978. Myocardial infarction in young vs old male rats: Pathophysiological changes. Am. Heart J., 96: 70-80. DOI: 10.1016/00028703(78)90128-X

4. Todd, G.L. and G.M. Cullan, 1980. Isoproterenolinduced myocardial necrosis and membrane permeability alterations in the isolated perfused rabbit heart. Exp. Mol. Pathol., 33: 43-54. DOI: 10.1016/0014-4800(80)90006- 4

5. Young, I.S., J.A., Purvis, J.H., Lightbody, A.A. Adgey and E.R. Trimble, 1993. Lipid peroxidation and antioxidant status following thrombolytic therapy for acute myocardial infarction. Eur. Heart J., 14: 1027-1033.

http://eurheartj.oxfordjournals.org/content/vol14/is sue8/index.dtl

6. Wexler, B.C., 1973. Protective effects of propanolol in isoproterenol induced myocardial infarction. Atherosclerosis, 18: 11-14. DOI: 10.1016/0021-9150(73)90114-7

7. Warrier, P.K., 1995. Indian Medicinal Plants: A Compendium of 500 Species. 1st Edn., Orient Longman, Madras, Blackswan, ISBN: 8125003037, pp: 444.

8. Kirtikar, K.R. and B.D. Basu, 1999. Indian Medicinal Plants. 2nd Edn., Allahabad, International Book Distibuters, Book Sellers and Publisher, ISBN: 817089056X, pp: 1139-1140. 
9. Naik, V.R., N.V. Agshikar and G.J. Abraham, 1980. Analgesic and anti-inflammatory activity in alcoholic extracts of Cucumis trigonus Roxburghii. A preliminary communication. Pharmacology, 20: 52-56. DOI: $10.1159 / 000137345$

10. Naik, V.R., N.V. Agshikar and G.J. Abraham, 1981. Diuretic activity of Cucumis trigonus Roxb. J. Ethnopharmacol., 3: 15-19. DOI: 10.1016/03788741(81)90011-8

11. Naveena, B.M., S.K. Mendiratta and A.S.R. Anjaneyulu, 2004. Tenderization of buffalo meat using plant protease from Cucumis trigonus Roxb (Kachri) and Zingiber officinale roscoe (Ginger rhizome). Meat Sci., 68: 363-369. DOI: 10.1016/J.MEATSCI.2004.04.004

12. Asif, U.M., K.S. Kim and Y.G. Yu, 2006. Purification and characterization of a serine protease from Cucumis trigonus Roxburghii. Phytochemistry, 67: 870-875. DOI: 10.1016/J.PHYTOCHEM.2006.02.020

13. Hevener, A., D. Reichart, A. Janez and J. Olefsky, 2002. Female rats do not exhibit free fatty acid-induced insulin resistance. Diabetes, 51: 1907-1912.

DOI: 10.2337/DIABETES.51.6.1907

14. Mohun, A. and I.J. Cook, 1957. Simple methods for measuring serum levels of glutamic-oxalo acetic and glutamic-pyruvic transaminase in routine laboratories. J. Clin. Pathol., 10: 394-399. DOI: $10.1136 /$ jcp.10.4.394

15. King, J., 1965. The Dehydrogenase of Oxido Reductase Lactate Dehydrogenase. In: Practical Clinical Enzymology, Van, D. (Ed.). Nostrand Co., London, pp: 83-93.

16. Okinaka, S., H. Kumogai and S. Ebashi., 1961. Serum creatine phosphokinase activity in progressive muscular dystrophy and muscular disease. Arch. Neurol., 4: 520-525. http://archneur.amaassn.org/cgi/content/summary/4/5/520

17. Sabeena Farvin, K.H., R. Anandan, S.H. Kumar, K.S. Shiny, T.V. Sankar and T.K. Thankappan, 2004. Effect of squalene on tissue defense system in isoproterenol-induced myocardial infarction in rats. Pharmacol. Res., 50: 231-236. DOI: 10.1016/J.PHRS.2004.03.004

18. Gürgün, C., M. Ildizli, O. Yavuzgil, A. Sin, A. Apaydin, C. Cinar and H. Kültürsay, 2008. The effects of short term statin treatment on left ventricular function and inflammatory markers in patients with chronic heart failure. Int. J. Cardiol., 123: 102-107. DOI: 10.1016/J.IJCARD.2006.11.152
19. Rajadurai, M. and S.M.P. Prince, 2006. Preventive effect of naringin on lipid peroxides and antioxidants in isoproterenol-induced cardiotoxicity in Wistar rats: Biochemical and histopathological evidences. Toxicology, 228: 259-268. DOI: 10.1016/J.TOX.2006.09.005

20. Zhou, B., L.J. Wu, L.H. Li, S. Tashiro, S. Onodera, F. Uchiumi and T. Ikejima, 2006. Silibinin protects against isoproterenol-induced rat cardiac myocyte injury through mitochondrial pathway after upregulation of SIRT. J. Pharmacol. Sci., 102: 387-395. DOI: 10.1254/JPHS.FPJ06005X

21. Rathore, N., S. John, M. Kale and D. Bhatnagar, 1998. Lipid peroxidation and antioxidant enzymes in isoproterenol induced oxidative stress in rat tissues. Pharmacol. Res., 38: 297-303. DOI: 10.1006/PHRS.1998.0365

22. Srivastava, S., B. Chandrasekar, Y. Gu, J. Luo, T. Hamid, B.G. Hill and S.D. Prabhu, 2007. Down regulation of $\mathrm{Cu}, \mathrm{Zn}$-superoxide dismutase contributes to beta-adrenergic receptor-mediated oxidative stress in the heart. Cardiovascul. Res., 74: 445-455. DOI: 10.1016/J.CARDIORES.2007.02.016

23. Padmanabhan, M. and S.M. Prince, 2007. Sallylcysteine ameliorates isoproterenol-induced cardiac toxicity in rats by stabilizing cardiac mitochondrial and lysosomal enzymes. Life Sci., 80: 972-978. DOI:10.1016/J.LFS.2006.11.028

24. Ithayarshi, P., V.N. Padmavathy and C.S. Shyamala Devi, 1996. Effect of $\alpha$-Tocopherol on isoproterenol-induced myocardial infarction in rats-electrocardiographic biochemical and histological evidences. Ind. J. Physiol. Pharmacol., 40: 297-302.

http://www.ncbi.nlm.nih.gov/pubmed/9055097

25. Seneviratine, C.K., L.I. Timao, N. Khaper and P.K. Singal, 1999. Effects of methionine on endogenous antioxidants in the heart. Am. J. Physiol. Heart Circ. Physiol., 277: 2124-2128. http://ajpheart.physiology.org/cgi/content/abstract/ 277/6/H2124

26. Peacock, W.F., J.E. Hollander, R.W. Smalling and M.J. Bresler, 2007. Reperfusion strategies in the emergency treatment of ST-segment elevation myocardial infarction. Am. J. Emerg. Med., 25: 353-366. DOI: 10.1016/J.AJEM.2006.07.013

27. Rajadurai, M. and S.M.P. Prince, 2007a. Preventive effect of naringin on cardiac markers, electrocardiographic patterns and lysosomal hydrolases in normal and isoproterenol-induced myocardial infarction in Wistar rats. Toxicology, 230: 178-188. DOI: 10.1016/J.TOX.2006.11.053 
28. Holland, R.P. and H. Brooks, 1977.TQ-ST segment mapping: Critical review and analysis of current concepts. Am. J. Cardiol., 40: 110-129. DOI: 10.1016/0002-9149(77)90109-6

29. Kela, A.K., L.P. Reddy and D.P. Thrombe, 1980. ECG findings in normal rats and after administration of isoproterenol. Ind. J. Physiol. Pharmacol., 24: 84-90.

http://www.ncbi.nlm.nih.gov/pubmed/7380532
30. Karthick, M. and S.M.P. Prince, 2006. Preventive effect of Rutin, a bioflavonoid, on lipid peroxides and antioxidants in ISO-induced myocardial infarction in rats. J. Pharm. Pharmacol., 58: 701-707. DOI: 10.1211/JPP.58.5.0016 